\title{
新生巟脳室内出血に伴う水監症の管理方法は？
}

本論文では，特発性血小板減少性紫斑病（ITP） に罹患する妊婦の胎児が胎内で脳室内出血を発症 し, 出生後に合併発生した水頭症に対して著者らが 行った治療経過が報告されている，本症例では，ま ず脳室髄液リザボアーを設置しここれをへして間欠 的に䯣液を排除することにより水頭症を管理，次い で脳室一腹腔短絡術が施行され治療が完遂してい る. 非常にまれな症例であるが, 新生児の血小板数 を測定しつつ治療方針を決定することが肝要である と，著者らによって述べられている，低出生体重児 や本症例のように全身合併症を有する脳室内出血後 の新生児水頭症の管理は，決して容易なものではな い. 脳室髄液リザボアーの設置は, 手術室でなくと

順天堂大学脳神経外科 新井 一

も NICU で行うことができるので，これらの症例の 水頭症の治療には有用な方法である。ただし，(1髄 液を急速に排除すると血圧や脈拍が大きく変動する ことがある，(2)髄液を慢性的に体外に排除すること により血液電解質異常をきたすことがあるといつた 点に留意する必要がある。また，通常は1日に 1 2 回脳室髄液リザボアーを穿刺して髄液を排除する が，大泉門の緊張の度合いや頭囲の変化を目安に髄 液排除量を決めることになる。しかしながら，一度 に排除できる髄液量に制限があるのも事実であり， 体重の増加や全身状態の改善を待って可及的速やか に脳室一腹腔短絡術に移行することが望まれる。

\section{ITP 合併妊娠による胎児期謄室内出血後水頭症をどう考えるか？}

今日, 特発性血小板減少性紫斑病 (idiopathic thrombocytopenic purpura；ITP）の内科的管理の進歩によ り妊娠症例も増加しつつある。また新生児の血小板 数が 5 万 $/ \mu l$ 以下の場合は頭蓋内出血などの重篤な 合併症が多い点や胎児血小板数の測定は困難である 点も事実である。近年の胎児超音波診断の進歩によ り, 従来早産児が出生後に診断されていた脳室内出 血・出血後水頭症が胎児期に診断される可能性も高 まっている，さらに欧米では胎児期頭蓋内出血の対 応として胎内治療が取り入れられている. 本論文は, ITP 合併妊娠による胎児期脳室内出血後進行性水頭 症の周術期管理について，わが国における脳神経外 科医の今日的観点からみた示唆に富む貴重な報告例 である。

ITP 合併妊娠の管理方針にはいくつかのガイドラ インがあるが，本症例のような頭蓋内出血ならびに 進行する水頭症の胎生期からの患児の管理について
東京医科大学脳神経外科 三木 保

の詳述はない. 本論文では, 複雑な本病態の予防, 治療の周術期管理の現時点でのポイントとして下記 の点を強調している. (1)胎児期を含む周術期管理と して頻回の定期的超音波による児の頭蓋内評価が頭 蓋内出血の診断評価としてきわめて重要である。(2) 妊娠中の血小板数が 5 万 $/ \mu l$ 以上に保たれていても 胎児血小板と相関しない可能性があり，胎児に頭蓋 内出血がみられた場合は出血増大予防の目的で何ら かの治療が必要である。母体への予防的なガンマグ ロブリンやステロイド㶡の投与，血小板輸血の検討 も必要である. (3)出生後の進行性水頭症に対しては, 新生児血小板が 5 万 $/ \mu l$ 以下ならばガンマグロブリ ンやステロイド剤の投与, 血小板輸血を行う。さら に Ommaya リザーバーによる水頭症管理後, 待機的 にシャント術を行う。以上のような指針が示され検 討に值するものと考える．今後さらなる症例の蓄積 による十分な検証が期待される。 